\title{
LELAKAK SASAK IN LOMBOK: AN ANALYSIS OF THE EDUCATIONAL VALUES
}

\author{
Lalu Nurul Yaqin, Karomi, dan Mawardi \\ Fakultas Keguruan dan Ilmu Kependidikan (FKIP) \\ University Of Gunung Rinjani, Lombok \\ Jalan Raya Mataram, Lb. Lombok, Kabupaten Lombok Timur, \\ Nusa Tenggara Barat, Indonesia \\ Email: layaqin@gmail.com
}

\begin{abstract}
ABSTRAK
Lelakak Sasak adalah salah satu bentuk puisi tradisional Sasak yang diiringi music dan umumnya sebagai alat komunikasi, hiburan, dan media pendidikan. Sebagai media pendidikan, Lelakak Sasak sering digunakan sebagai media untuk memberi saran dan bimbingan untuk masyarakat, anak-anak, dan yang lain-lain. Oleh karena itu, Lelakak Sasak adalah salah satu hal yang penting untuk dikembangkan. Penelitian ini bersifat deskriptif kualitatif, karena menginisiasi untuk memberikan gambaran terkait nilai pendidikan dalam Lelakak Sasak di Selaparang. Teknik yang digunakan dalam mengumpulkan data adalah wawancara, dokumentasi, dan perekaman. Teknik wawancara adalah teknik yang digunakan untuk mengumpulkan data dengan mengajukan pertanyaan langsung kepada para informan. Dalam penelitian ini, peneliti mewawancarai delapan informan. Teknik dokumentasi adalah pelaksanaan studi literature untuk mendapatkan data yang dapat digunakan sebagai referensi dalam memahami Lelakak, dan teknik perekaman dilakukan oleh peneliti pada masyarakat Selaparang. Hasil kajian ini mendapati nilai-nilai pendidikan dalam Lelakak Sasak adalah: 1) Nilai pendidikan agama, isinya beberapa pelajaran seperti rasa syukur kepada Tuhan, saling mencintai. 2) Nilai pendidikan moral, mengandung moral manusia, dan 3). Nilai pendidikan sosial, berisi beberapa pelajaran seperti sikap kebersamaan umat manusia, sikap persaudaraan dan sabar.
\end{abstract}

Kata Kunci: lelakak sasak; lombok; nilai-nilai pendidikan

\section{ABSTRACT}

Lelakak Sasak is one form of Sasak traditional poetry which is followed by music and commonly as a kind of communication, entertainment, and educational media. As education media, Lelakak Sasak often used as media of giving suggestion and guidance for people, children, and the others. Therefore, Lelakak Sasak is one important thing to be developed. This study is descriptive qualitative, since it is initiating to give a description of forms and educational values of Lelakak Sasak at Selaparang. The techniques used in collecting data are interview, documentation, and recording. The interview technique is a technique which is used to assemble the data by raising the direct question to the informants. In this study, the researcher interviewed eight informants. The documentation technique is the implementation of literature study to get the data that can be used as references in understanding Lelakak, and recording technique is done by the researcher around Selaparang society. The study reveals that the educational values in LelakakSasak are: 1) Religious educational value, it contents some lesson such as thankfulness to God, loving each other. 2) Moral educational value, it contains a human's moral, and 3). Social educational value, it contents some lesson such as the attitude of togetherness of humanity, it contents the attitude of brotherhood and patient.

Keywords: Lelakak Sasak; Lombok; Educational values 


\section{INTRODUCTION}

Literature constitutes a form of art established through the beauty of language use, the original of ideas to be expressed and the important messages which are delivered orally or in written form, Yaqin (2015). In the beginning, these terms are involving all kinds of written knowledge whereas, in further development, this term in the Indonesian language refers to literature.Literature is one element of culture used to express the mind and sense of people. It has been much expressing the people's phenomena and their environment. Literature as a medium of expression or statement reflects the principles such as an element of the system, educational values, and ideas of culture mean that it can influence the people's life phenomena and environment.

Concerning with Lelakak Sasak, it constitutes part of an old literature which is still having educational values relevant with contemporary values, and it is still learned because it contains high values, on the other hand, Lelakak Sasak as a part of an old literature contains values such as moral, social, and religious values, Himawan \& Suhandano (2012). An old poetry in Indonesian poetry is not influenced by western culture such as Sair, Mantra, Pantun, Gurindam. If we pay more attention to the literary works, Lelakak Sasak constitutes one of an old poetry which is usually sung by our forefathers or and generally inherited orally from one generation to the next generation,(Satrya, 2017; Jayadi, 2018). Local culture, according to Yusuf (1995:257) is a literary work from one region in one of a certain culture which constitutes the properties of national culture or tribes of the nation.

Furthermore, according to Kamus Bahasa Sastra Sasak, Lelakak consists of four lines (Azhar 1997:53). It means that Lelakak Sasak has sameness verses with Pantun as an old poetry; Yusup (1995:209) states that Pantun is one type of old poetry in Malay literature. It consists of four lines, every line consists of four words with its patterns such as $a-b-a-b$, and the two first lines are called Sampiran. The third and fourth lines are called meaning (isi). Based on the opinion above, it can be concluded that Lelakak Sasak has rhyme and rhythm which is usually sung and danced. According to the tradition of Lelakak Sasak, it is delivered orally and inherited from generation to next generation. Nowadays, it has been regarded as an old thought or out of date to be performed as an entertainment and educational media, especially among the young generation. On the other hand, Lelakak Sasak will not exist anymore it's pushes the researchers to collect forms and educational values of Lelakak Sasak. If the people do not care about it, Lelakak Sasak is being threatened to end. 


\section{METHODOLOGY}

This study is categorized into a qualitative method because it is in accordance with the aims of this study to describe and analyze the educational values of Lelakak Sasak. Bogdan and Biklan in Yaqin (2017) indicated that qualitative research has some characteristics as follows:
a. Having one natural setting.
b. Using the researcher as the key instrument.
c. Having much concerned with process than outcome
d. Descriptive in nature.
e. Having much more utterances or words as the data
f. Analyzing the data inductively.

\section{DATA AND SOURCE OF DATA.}

The data in this research is Lelakak Sasak containing educational values. Then, sources of the data in this research are public figures and artists who understand and practice Lelakak Sasak. Furthermore, in this research, it took six informants as a source of data investigation, and forms of data are Lelakak Sasak is song by the singer of Lelakak.

\section{THE TECHNIQUE OF DATA COLLECTION}

The technique used in collecting data is documentation. The documentation technique is the implementation of a literary study to get the data that can be used as references in understanding LelakakSasak. Furthermore, the interview technique is used by the researcher to collect the data by applying a direct question to the informants. The process of the interview is recorded to reinforce the result of the interview between the researcher and informants around Selaparang village.

According to Moleong (2000: 161), documentation has been used for a long time as the data source of investigation, because document as a source of data has been used in many cases to examine and interpret, even to predict a data.

\section{THE TECHNIQUE OF DATA ANALYSIS}

In qualitative research, the data analysis conducted since data begin gathered in order the research them back and forth the data have been composed with the next data. Patton in Moloeng (2000: 103) stated that data analysis is the process in writing the data, organizing into categorizing pattern, and unit of base description. While Muhammad (2000: 18) stated that the analysis is a process of searching out arranging systematically the interviewer transcripts, documents study, recording transcripts, field note, and the other collecting data. It is done to make it easier for the researcher understanding, interpret, and write the researcher report. Moreover, the data analysis in 
this researcher is done through two phases such as: first, the data analysis is processed during the activity of data collection in the field. Second, the data analysis is done after data collection (Yaqin, Seken \& Swarnajaya, 2013: Yaqin, 2018).To assess the educational values of Lelakak Sasak, it used two points of technique such as descriptive technique is used to describe the educational values of Lelakak Sasak, and interpret technique will use to interpret the educational value.

\section{TRUSTWORTHINESS OF THE DATA.}

In determining the trustworthiness of the data, it needs some techniques. In this case, the researcher used a triangulation technique; it used to check the trustworthiness of the data description and the result of the investigation. This technique, the researcher conducted to compare the finding based on the time of collecting the data. Then, in this study, there are three ways of triangulation of data that the researcher did. Those are, utilizing data source, a method of data collecting, and help other colleagues (Yaqin, 2015)

\section{FINDINGS AND DISCUSSIONS}

In a society of Selaparang culture, there are many kinds of Lelakak Sasak that contains suggestion and it has high values that can be used as a way of life and guidance in their daily activity.Lelakak Sasak as a part of the local culture was getting a decline from time to time. It is caused by the singer of Lelakak Sasak are not much before. So, the position of Lelakak Sasak as a part of local literature must be preserved and developed seriously. Talking about the decrease of traditional expression from generation to generation, it is caused by the lack of inheritance of Lelakak. The inheritance (Bearer) can be categorized into two categories as follows: Passive and active bearer. The passive bearer is bearer who knows about the form of folklore only or having no interested to separate it for the people actively but active bearer is bearer who knows about folklore and separates it (Dananjaya, 1984:3). In the same situation, it is also used by the people who know about Lelakak Sasakor another traditional expression because there are only a few people who can memorize Lelakak Sasak itself, Jamaluddin, Seken, \&Artini, (2013).

Based on the statement above, the existence of Lelakak Sasak from generation to generation has been getting decreasing because the passive bearer is much more than an active bearer (inherited). Therefore, Lelakak Sasak as a local culture was getting underdeveloped from time to time.

\section{THE FORMS OF LELAKAK SASAK}

Lelakak Sasak as a kind of old poetry which has certain characteristics. According to Koentjaraningrat, Budhisantoso, Danandjaya, \&Suparlan, (1984). that the forms of sentences are 
not free, but they have rhymes and forms as a literary work. Based on the forms of traditional expression obtained in Lelakak Sasak, it can be said that Lelakak Sasak as a folklore has certain characteristics as oral folklore. Furthermore based on the result of the investigation so, the researchers make the quotation about the form of Lelakak Sasak Selaparang society as follows:

1. Lelakak Sasak contains four lines

2. The two first lines are called Sampiran and two and second lines are called Isi

3. Having A-B-A-B rhyme

4. Contains a guidance and suggestion

\section{DATA DESCRIPTION}

Referring to the research that has been conducted, in this section the researcher will present the some samples data of Lelakak Sasak(LS) as data below:

\begin{tabular}{|c|c|}
\hline $\begin{array}{l}\text { O1. Apakandoqmangantengari } \\
\text { Kelaqlebuisedaqbawang } \\
\text { Apatandoqummatnabi } \\
\text { Pacu-pacungajisembahyang }\end{array}$ & $\begin{array}{l}\text { What are the vegetables for having lunch } \\
\text { Cooking long beans and onions } \\
\text { What are the characteristics of Muhammad } \\
\text { followers } \\
\text { Be diligent to recite Al-qur'an and praying }\end{array}$ \\
\hline $\begin{array}{l}\text { O2. Kadalnongaqleqkesambik } \\
\text { Benangkataqsetakilan } \\
\text { Tajahonyakendeqnamatiq } \\
\text { Payusalaqkejarian }\end{array}$ & $\begin{array}{l}\text { The lizard face up under the Kesambik tree } \\
\text { The roll of string } \\
\text { Disobeying a suggestion } \\
\text { Then, get misery }\end{array}$ \\
\hline $\begin{array}{l}\text { 03. Gegodoh pisang lendang } \\
\text { Timuq bending kailijaga } \\
\text { Beboto hendeqna menang } \\
\text { Kereng pelung bueq besanda }\end{array}$ & $\begin{array}{l}\text { The fried banana at the garden } \\
\text { East dam of Kalijaga village } \\
\text { No gain in gambling } \\
\text { All clothes were pawned }\end{array}$ \\
\hline $\begin{array}{l}\text { 04. Pacupacutaletbawang } \\
\text { Belimbingserintelaga } \\
\text { Pacu-pacungajisembahyang } \\
\text { Jaridindingapineraka }\end{array}$ & $\begin{array}{l}\text { Hard working in planting onions } \\
\text { Star fruit on the edge of the pool } \\
\text { Be keen in praying } \\
\text { As the shield of hell }\end{array}$ \\
\hline $\begin{array}{l}\text { 5. Endaqrenggajeruqmanis } \\
\text { Jeruqmanisataslangan } \\
\text { Endaqwedakanaqnagis } \\
\text { Kanaqnangislapahmelemangan }\end{array}$ & $\begin{array}{l}\text { Do not cut the orange trees } \\
\text { The orange trees on the street } \\
\text { Do not bother the crying child } \\
\text { The crying child wants to eat }\end{array}$ \\
\hline $\begin{array}{l}\text { 06. Munperaulewatgili } \\
\text { Ku Panto ularberanaq } \\
\text { Adeng-adengsiksidasili } \\
\text { Ndeq da ketaonpikirankanaq }\end{array}$ & $\begin{array}{l}\text { The canoe sail the sea } \\
\text { I watch a snake giving birth } \\
\text { don't be angry easily } \\
\text { you do not know his thought }\end{array}$ \\
\hline
\end{tabular}




\begin{tabular}{|c|c|}
\hline $\begin{array}{l}\text { 07. Kepundungkebonbintaro } \\
\text { Anaqmayungjariberongga } \\
\text { Beruntungendeqnakado } \\
\text { Masih payujariroga }\end{array}$ & $\begin{array}{l}\text { Kepundung tree at Bintaro garden } \\
\text { A deer as a cut off the tree } \\
\text { Fortunately for getting married } \\
\text { But it will be big problem }\end{array}$ \\
\hline $\begin{array}{l}\text { 08. Rangdumalangdayandesa } \\
\text { Kelor kampung bekelentang } \\
\text { Solahbajangjaridedara } \\
\text { Meormambumaraqkekembang }\end{array}$ & $\begin{array}{l}\text { Randu tree crosses at north village } \\
\text { Kelor tree is leafy } \\
\text { young beautiful girl } \\
\text { Sweet smell like a rose }\end{array}$ \\
\hline $\begin{array}{l}\text { 09. Ali-aliselakselaka } \\
\text { Singgakrendenggubuklauk } \\
\text { Bejanjibulanpuasa } \\
\text { Endarakkerengjaknajauk }\end{array}$ & $\begin{array}{l}\text { The rings among the silver } \\
\text { Borrowing a Rendeng at north village } \\
\text { Make a promise at the fasting month } \\
\text { Bring no clothes }\end{array}$ \\
\hline $\begin{array}{l}\text { 10. Koloduaseperugak } \\
\text { Ngeraenaenjelo } \\
\text { Bodo ruanendeqtebaudugaq } \\
\text { Selaerengkossejelo }\end{array}$ & $\begin{array}{l}\text { Two pairs of the turtledove at Berugak } \\
\text { It is sunset time } \\
\text { Unpredicted fool man } \\
\text { It's beyond to our thought }\end{array}$ \\
\hline $\begin{array}{l}\text { 11. Topat lima sekeraro } \\
\text { Dadal Manis ataslangan } \\
\text { Kocap side gindalalo } \\
\text { Tangis side beselaman }\end{array}$ & $\begin{array}{l}\text { Five of Tupat in a basket } \\
\text { The sweet of soft rice on the street } \\
\text { You said that you will go } \\
\text { You are crying when shaking hands }\end{array}$ \\
\hline $\begin{array}{l}\text { 12. Ku belauqkubedaya } \\
\text { Muntengkoahrajanglambah } \\
\text { Munkumauqpadanwaya } \\
\text { Jaq kuroahinggasbegabah }\end{array}$ & $\begin{array}{l}\text { I went to north and south } \\
\text { The Tengkoah bird stepping across the fence } \\
\text { If I got the same age level } \\
\text { Making a party after the harvest }\end{array}$ \\
\hline $\begin{array}{l}\text { 13. Belek bangketsakberaik } \\
\text { Munberaiksayanlimpah } \\
\text { Beleqangensaqbedait } \\
\text { Yen bedaitsayanisah }\end{array}$ & $\begin{array}{l}\text { Wide irrigating in the field } \\
\text { More irrigating overtopping } \\
\text { Longing heart for date } \\
\text { When dating, we get forbear stay }\end{array}$ \\
\hline $\begin{array}{l}\text { 14. ApaawisleqlendangMujur } \\
\text { Awuispandanjarilangan } \\
\text { Apatangisleqdalemkubur } \\
\text { Tangisawaqendek arak amal }\end{array}$ & $\begin{array}{l}\text { What are cutting down in Mujur Garden } \\
\text { Cutting Pandan leaf as a street } \\
\text { What are crying in the grave } \\
\text { Body crying no deed }\end{array}$ \\
\hline $\begin{array}{l}\text { 15. Sampinsaiataslangan } \\
\text { Sampindengan along mate } \\
\text { Endaqpatiqkeratendengan } \\
\text { Kerantendengan talon ate }\end{array}$ & $\begin{array}{l}\text { Who does have cows on the streets } \\
\text { The others cows are all death } \\
\text { Don't trust the human slander } \\
\text { The human slander are jealous }\end{array}$ \\
\hline
\end{tabular}




\section{LELAKAK SASAK AND EDUCATIONAL VALUES}

The existence of LelakakSasak in Selaparang society has close relationship with educational values. It can be used as a guidance in our daily activity. The educational values in LelakakSasak have several kinds, includes all aspects of society life. It can be seen from its contents.

There are many values containing in LelakakSasakSelaparang such as follows:

1. Religious educational value can be used as a good guidance for the other people. Furthermore, it contains of fear and faith values to the the God in order that we always remember Him and glorify the fear and faith.

2. Moral educational value can be used as a having-standard in doing good behavior.

3. Social educational value can be used as a foundation of life in order that we care to help each other.

Based on the statement of the problems, it is necessary to analyze and describe the educational values that appear in LelakakSasakSelaparang such as: Religious Educational Value, Moral Educational Value, and Social Educational value:

\section{RELIGIOUS EDUCATIONAL VALUES}

In presenting the religious educational value, it is necessary to clarify what the word "religion" means. Religious is system of faith and worship based on the belief. Religion is a valuable part of human life in the world. Religion can be example, rule, and motivation of human to get a prefer quality of life. Lelakak sasak have many religious educational values which is used as guidance and suggestion such describe in LS 14, LS 01, LS 03, and LS 04. The elaboration of each LS can be shown as follows. LS No 14 describes the people in their life time who always reluctant in doing good works after passing way. Their life will be suffer because they feel regret in the day after. The reward in the day after is the good deed that is done during their life time.

This Lelakak is one kind of Lelakak Sasak Selaparang that contains religious educational value, and it has high potential in society life because it contains a good suggestion and guidance for doing good deeds in our daily life. LS No. 1 describes the people who needs peaceful in the world and in the day after. The people who love the the God are the people who love themselves, love the Creator, and they should undergo their duties such as five time prayers during day and night. Furthermore, Lelakak Sasak above teaches us to perform praying because it is the fundamental of Islam, and it will enable us to avoid something bad. Furthermore, prayer is the way to calm down the heart and impure the soul, and it's also used as the way of communicating between mankind and The God. The Lelakak educates us to obey The God ordered seriously; it is one of the ways to get peaceful both in the world and the day after. By understanding this Lelakak, we can realize our obligation as the infinite slave for obeying His order and avoid His prohibition. 
Based on the explanation above, this Lelakak can be categorized into religious educational value. It will enable us to increase the consciousness to do our duties and religious order. LS. No. 03 "Bebotohendeqnamenang" (the third lines); this Lelakak describes someone who always loses in gambling and he has never gotten a luck in playing it. Moreover, "Kerengpelungbueqbesanda" (fourthline) describes all kinds of wealth he has; what he gets are sold and pawned for gambling and what he does is the beginning of being a poor man. So, this Lelakak is used as a suggestion and guidance in order to avoid gambling in daily activity. Furthermore, the Lelakak is also hoped as a medium of avoiding regret feeling in order we are not affected for doing and plying gamble, and we should realize about what must be done and what must be avoided. Therefore, it can be concluded that Lelakak Sasak contains religious educational value, because it suggests us to avoid playing gamble. On the other hand, Islamic Syari'at also prohibits us not to play gamble. It enables us to be reluctant in doing something. LS. No. 04, contains of educational value, we are obliged to gain the knowledge seriously especially religion education, and we are suggested to apply it in daily life. By understanding the meaning of Lelakak above, it will enable us to increase the consciousness to gain knowledge because gaining knowledge is a part of Islamic teaching to gain rewards heaven in the hereafter. According to belief, obeying can defend sinful person from the fire of hell.

Base on the explanation of each LS above the researcher identified that all the LS classified involve religious educational values because they suggested religious messages such :
a. Obeying His order and avoiding His prohibition.
b. Motivating people for doing syari' at ordered.
c. Enrich good deed throughout our life.

\section{MORAL EDUCATIONAL VALUES}

Generally, moral concerns with goodness and badness of human character, between right and wrong. Moral concerns with rules and standard of human behavior, in other words goodness and badness is relative. It means that the view of life of a nation is not the same with the others. Relating to the moral value, in Lelakak Sasak Selaparang also have many suggestions and guidance which contains moral values, as shown at LS.11, LS. 02, LS.10, LS.12, LS.15, LS.06, LS.07,LS.08, and LS.09.The elaboration of each LS can be shown as follows.

LS.No.11, “Kocapsidagindalalo, tangis side beselaman". Understanding the meaning of LelakakSasak above can persuade us to understand and comprehend the misery felt by the people who is left by their beloved partners. Besides that, this Lelakak also describes the condition of a girl who is left by her sweetheart. So, this Lelakak gives a message to the people who are away, and do not forget their beloved partners.LS No. 11 also suggests man to appreciate the loyalty of women. The happiness and sadness are shared together and defend the unity of her family. So, this Lelakak 
contains of moral educational value such as: love, loyalty, and responsibility. The people who do not want to hear the good suggestion and guidance from others will not get safety in their life. The good advice and guidance can be used as a basic way in a society life.

Furthermore, good suggestion from other people must be heard, cared, and it should be applied seriously in our daily life. Don't neglect any suggestion in order that our life can be peaceful. So, Lelakak Sasak above can be included that it has moral educational value, because it purposes to educate us to hear someone's suggestion and apply it in our daily activity. Lelakak No.10 suggests us not to underestimate the people because the people whom we underestimate may be better than us. Many people judge someone from his/her performance only. Performance is not a guarantee of someone whether they have a good behavior or not, moreover, performance is frequently does not always tell the reality. So, making a judgment to someone is not only concerning with the appearance only, but also we should know their personality.

Sometimes, the people who look like plain and calm are very difficult to guess their personality. Plain characteristics are not the guarantee that they have good attitude. This Lelakak warns women to be careful in accepting man as her partner. The Lelakak also suggests that in choosing the partner she should not be hurry in order that she is avoided from regret.

Based on the explanation above, the Lelakak has a moral educational value, because it gives the suggestion for women to be selective in choosing partners.LS No.12 is a form of Lelakak Sasak which describes about how important it is, to make a decision in getting marriage. The couple had to for an appropriate time to do it. It means that all marriage preparation and planning should be set up completely as presented in the last line "Ku roahinggas begabah". In this line, we can see that a man will make a decision after having a harvest time. Because after harvesting time, women believers that the man will be able to give guarantee the life of the women (material and spiritual). So, it can be said that LelakakSasak above contains of moral educational value, because it suggests us to prepare our marriage comprehensively before conducting it, in order the wedding ceremony is running well without any trouble. LS 15 is a kind of Lelakak Sasak which is sung by Selaparang society. It can be seen from the quotation of "Endaqpatiqkerantendengan, kerantendengan talon ate" is giving the density in order that we do not trust information media, news, or story before knowing and getting the evidence directly. Understanding the meaning of Lelakak Sasak enable us to increase the consciousness feeling in doing something, thinking positively and using good mind as perspective the problem.LS 06 is a kind of Lelakak Sasak Selaparang which is used as guidance in educating the child. The child is the God entrust must be kept and educated in order that they will be useful child for society and country Furthermore, this Lelakak also has an effect in determining the personality of children in order to obey their parent's suggestion. 
Based on the explanation above, it can be concluded that the Lelakak consists of a moral educational values. LS07 is a form of Lelakak used by Selaparang society as a way for giving the suggestion to man who wants to get married in order to be careful to do it. Lelakak Sasak above also gives man the suggestion that he should have preparation before conducting it, because, marriage is not for biological needed but also it needs comprehensive preparation mentally and physically.

Based on the explanation above, the Lelakak contains of moral educational are able to increase awareness feeling of men who want to get married, and he should have preparation in order to avoid marital problem. The quotation of Lelakak Sasak above used as an illusion of beautiful girl, even it is indicated as blossom flower. Furthermore, a girl should have no beautiful face but she should have beautiful performance, good moral in interacting with the other in a society life. The Lelakak is sung by Selaparang society because, it contains a moral educational value which is used as guidance for a girl who want to live well in society life. It is also used as a media for giving advice by the parents in doing positive activities in our daily activity. The Lelakak educates the society particularly (teenagers) of Selaparang village not to get marry too early, and not to be hurry in making decision. This Lelakak is still sung by the people and it is contributes influence in society life.By understanding this Lelakak, it will enable us to increase an awareness of feeling and responsibility. Marriage is not for biological needs but also it needs a comprehensive preparation mentally and physically. Based on the description above, Lelakak above contains of moral educational value which is suggesting us not to be hurry to make a decision.

Base on the explanation of each LS above the researcher clarified that all kinds of the LS involves moral educational values because they suggested moral messages such :

a. Do not be easy to accept the good suggestion from someone else

b. Women is hoped to be selective in choosing partner in order to avoid from regret feeling.

c. Having social consciousness for helping someone else

d. Having good high attitude in society life

\section{SOCIAL EDUCATIONAL VALUES}

Many social educational values that appear in LelakakSasak such as love, togetherness, religion, society etc. describe in LS.13, and LS.05. The elaboration of each LS can be shown as follows. LSNo.13 describes about the couple who are falling in love. These two couple has been separated by the distance and time. They are falling in love and longing for each other. They are really expecting a moment when they might meet. Finally, their dreams become true and they live together happily. Based on the explanation above, this Lelakak Sasak contains of social educational value which expresses one kind of togetherness.LS No.05 is a kind of Lelakak describes an orphan who always sad from place to place because it is hoping the pity from other people, it future is 
vague because has no family. The orphan hopes an attention from other people, and without their attention, their life will be sorrow. Lelakak suggests us as member of society we should care to the crying child. Furthermore, it values concerning to social educational values which aims for helping, taking care, and establishing them properly.Based on the explanation of each LS above the researcher clarified that all kinds of the LS involves social educational values which is suggest one kind of togetherness, helping the others, taking care, and establishing them properly.

\section{CONCLUSIONS AND SUGGESTIONS}

\section{Conclusions}

Based on the result of the discussion in chapter IV, the researchers takes some conclusions as follows:

1. Lelakak Sasak at Selaparang as part of local culture was rarely found because the singers of Lelakak Sasak are not existing anymore.

2. Lelakak Sasak at Selaparang has certain patterns a-b-a-b rhyme

3. Lelakak Sasak at Selaparang consists of four lines, the first and the second lines are called Sampiran, and the third and the fourth are called Isi (content)

4. Lelakak Sasak at Selaparang is not only a kind of traditional expression, but also there are many educational values in it such as religious, moral, and social educational values and they can be used as guidance in our daily life.

\section{Suggestions}

Referring to the research result, discussions and conclusions, the researchers would like to present some suggestions as follows:

1. For the societies, especially Selaparang society, it is hoped that the result of this research can be used as guidance in investigating the values and norms contained in Lelakak of Sasak.

2. Further researchers are expected to use the result of this research as a guidance to conduct further researches and try to develop the result of this research creatively.

\section{REFERENCES}

Azhar, Muhammad. (1997) Kamus Bahasa Sastra Sasak Indonesia. Mataram. Lombok: PT. IntanPariwara.

Fananie, Zaenuddin. 2000 Telaah Sastra. Jakarta: Muhamadiyah University

Himawan, Y. H., \& Suhandano, M. A. (2012). Lelakaq dalam Budaya Sasak (Analisis Etnolinguistik) (Doctoral dissertation, Universitas Gadjah Mada). 
Jayadi, U. (2018). Bentuk, Fungsi, dan Makna Lelakaq Sasak Sebagai Media Kampanye Calon Walikota Mataram. Prasasti: Journal Of Linguistics, 3(1), 139-150.

Jamaluddin, Seken, I. K., \&Artini, L. P. (2013). Analisis Bentuk, Fungsi dan Makna Lelakaq dalam Acara Sorong Serah pada Ritual Pernikahan Adat Sasak. Jurnal Pendidikan dan Pembelajaran Bahasa Indonesia, 2.

Koentjaraningrat, K., Budhisantoso, B., Danandjaya, J., \&Suparlan, P. (1984). Kamus Istilah Antropologi. Pusat Pembinaan dan Pengembangan Bahasa.

Moleong. Lexy J. (2000). Metodologi Penelitian Kualitatif. Bandung: PT Remaja Rosdakarya Offset.

Nasir. (2002). Rangkuman Teori Sastra (DIKTAT). Mataram FKIP: UniversitasMuhammdiyah.

Satrya, H. D. (2017) Lelakak Sasak, Kearifan Yang Ternaturalisasi. Basindo, 1(1), 46-59.

Tarigan, Henry Guntur. (1985). Prinsip Dasar-Dasar Sastra. Bandung: PT. Angkasa

Yaqin, L. N., Seken, K., \&Suarnajaya, W. (2013). An Analysis Of Pembayuns Speech Acts In Sorong Serah Ceremony Of Sasak Marriage: A Ritualistic Discourse Study. Jurnal Pendidikan Bahasa Inggris Indonesia, 1.

Yaqin, L. N. (2015). An Analysis Of The Ideological Viewpoint In The Novel "The Da Vinci Code" Written By Dan Brown; A Literary Work Study. Jurnal Ilmiah Rinjani, 2(2).

Yaqin, L. N. (2017). Retorika Hj. Wartiah: Kuasa Bahasa Perempuan Suku Bangsa Sasak. Sawah Institute. Malang

Yaqin, L. N. (2018). Analisis Invensi Strategi Retorika Hj. Wartiah. Jurnal Ilmiah Rinjani, 6(1).

Yusuf, Suhendra. (1995). Leksikon Sastra. Bandung: Penerbit Mandar Maju. 